The Impact of Caregivers' Expressed Emotion and the Patients' Perception of Expressed Emotion on the Positive and Negative Symptoms of Patients with Schizophrenia in a Sample

\section{From Turkey}

\section{ABSTRACT}

The impact of caregivers' expressed emotion and the patients' perception of expressed emotion on the positive and negative symptoms of patients with schizophrenia in a sample from Turkey

Objective: Although the effects of caregivers' expressed emotion on the relapse of patients with schizophrenia have been studied widely, there is a relative paucity of research on how the patients' perceived expressed emotion affects outcome in schizophrenia. The main aim of this study was to examine the relative impacts of patients' perceived expressed emotion and the caregivers' expressed emotion on the symptom severity of patients with schizophrenia.

Method: In this prospective study, at the first assessment session, 116 stable patients were administered the Perceived Expressed Emotion Scale (PEES), the Positive and Negative Symptom Scale for Schizophrenia (PANSS) as the primary outcome measure. Their caregivers were administered the Expressed Emotion Scale (EES). At the second assessment six months later. PANNS was re-administered to the patients.

Results: The patients' perceived expressed emotion was more important than caregivers' expressed emotion on symptom severity. It was found that patients' perceived criticism/hostility $(\mathrm{C} / \mathrm{H})$ was a risky element on positive and negative symptoms, and on the total scores of PANSS. Patients' perceptions of emotional over-involvement (EOI) appeared to be stronger protectors against relapse than $\mathrm{C} / \mathrm{H}$.

Conclusion: Family environments with high EOI may protect against relapse in patients with schizophrenia. This finding can be interpreted in cross-cultural context. Psychosocial interventions should foster and maintain according to the cultural differences. The limitations and clinical implications of the results and directions for future studies were suggested.

Key words: Expressed emotion, perceived expressed emotion, positive and negative symptoms, schizophrenia

\section{ÖZET}

Türkiye'den bir örneklemde şizofreni tanısı alan hastaların pozitif ve negatif belirtileri üzerinde bakımverenlerin duygu dışavurumu ve hastaların algıladığı duygu dışavurumunun etkisi

Amaç: Şizofreni tanııı alan hastaların hastalıklarııın nüks etmesi üzerinde bakım verenlerin duygu dışavurumunun etkisini araştıran çok sayıda araştırma bulunmakla birlikte, hastaların tarafindan algılanan duygu dışavurumun hastalık sonucu üzerinde nasıl bir etkisi olduğu konusunda araştırmalar azdır. Bu çalışmanın ana amacı şizofreni tanııı olan hastaların belirti düzeyi üzerinde bakım verenlerin duygu dışavurumu ve hastalar tarafindan algılanan duygu dışavurumunun etkisini incelemektir.

Yöntem: Yapılan uzunlamasına çalışmanın ilk değerlendirme oturumunda 116 stabil durumda olan hastaya Algllanan Duygu Dişavurumu Ölçeği (ADDÖ), temel sonuç ölçümü olarak Şizofreni için Pozitif ve Negatif Belirti Ölçeği (PANSS) uygulanmıştır. Bakım verenlere ise Duygu Dışavurumu Ölçeği (DDÖ) verilmiştir. Altı ay sonraki ikinci değerlendirme oturumunda, hastalara PANSS yeniden uygulanmıștır.

Bulgular: Hastaların alglladıkları duygu dışavurumu bakım verenlerin duygu dışa vurumuna göre belirti düzeyi üzerinde daha önemli bir unsur olmuştur. Hastaların bakım verenlerinden algıladıkları eleştirel oluş / düşmanlık PANSS ile elde edilen pozitif ve negative belirtiler ve toplam puanlar üzerinde riskli unsur olarak bulunmuştur. Hastaların algıladıklan bakım verenlerin aşııı koruyucu kollayıcı oluşları eleştirel oluş / düşmanlığa göre depreşmeye karşı daha koruyucu bir unsur olarak görünmektedir.

Sonuç: Aşıı koruyucu kollayıcı olan aile ortamı șizofreni tanııı olan hastaların depreșmelerine karșı koruyucu bir faktör olabilir. Bu bulgu kültürel bağlam içinde değerlendirilmelidir. Psikososyal müdahalelerin sosyokültürel farklliklara göre düzenlenmesi ve yürütülmesi gerekir. Çalışmanın klinik doğurguları ve sınırlıkları ile ileriki çalışmalar için öneriler sunulmuştur.

Anahtar kelimeler: Duygu dışavurumu, algılanan duygu dışavurumu, pozitif ve negatif belirtiler, şizofreni

\section{Gulbahar Bastug', Nuray Karanci ${ }^{2}$}

'Assoc. Prof. Dr., Ankara University, Vocational Health School, Ankara - Turkey 2Prof. Dr. Middle East Technical University, Department of Psychology, Ankara - Turkey
Address reprint requests to / Yazıșma adresi: Assoc. Prof. Dr. Gulbahar Bastug, Ankara University, Vocational Health School, Fatih Caddesi, 06290 Kecioren/Ankara, Turkey Phone / Telefon: +90-312-357-3242

E-mail address / Elektronik posta adresi: baharbastug@gmail.com

Date of receipt / Geliş tarihi: May 19, 2014 / 19 Mayis 2014

Date of acceptance / Kabul tarihi: July 31, 2014 / 31 Temmuz 2014 


\section{INTRODUCTION}

Chizophrenia is a mental illness posing great difficulties for the patients and their families. Due to its chronic nature, it is important to understand factors related to symptom severity and prognosis of patients with schizophrenia. The concept of expressed emotion (EE), which has been shown to be an important predictor of relapse and well-being, refers to the affective attitudes and behaviors (such as criticism, hostility, and emotional over-involvement [EOI]) of a relative towards a psychiatric patient (1). Kazarian (2) defined EE in families with a mentally ill patient as emotional attitudes and behavior of the other members towards the mentally ill member. Furthermore, EE is depicted as a toxic element or a potentiator of relapse in patients with schizophrenia. There is considerable support from research studies conducted in a variety of different countries supporting the relationship between EE and the relapse process for schizophrenia (3-6). Based on these results caregivers' $\mathrm{EE}$ and its reduction became a target for interventions (7-10).

However, it is also important to understand how patients perceive EE and the effects of their perceptions on the course of their illness. How the patients view and evaluate the EE of their family was described as perceived EE (PEE) (11). Although research based on the relationship between $\mathrm{EE}$ and relapse started in the 1950s, the role of the patients' perceptions of EE of their caregivers on relapse has not been considered until Hooley and Teasdale's study (11) of depressed women. They argued that an objective rater's report of caregiver's criticism was less important than the patient's perception of that criticism. In a recent study (12), it was found that white and Latino family members who expressed more criticism were indeed perceived as more critical by the patients. However, among blacks, no significant association was found between relatives' expressed criticism and patients' perceived criticism. Research studies (13-15) show that PEE is a valid and reliable measure. In a meta-analysis of the validity of perceived criticism, Perceived Criticism Measure (PCM) was seen as a consistent predictor of treatment outcome (16). However, studies on the relative power of $\mathrm{PEE}$ and $\mathrm{EE}$ in predicting relapse are sparse and have produced mixed results. Scott et al. (17) found that schizophrenic patients who expected their parents to view them negatively were significantly more likely to relapse than those who expected their parents to view them positively. Lebell et al. (18) concluded that patients with positive perceptions of their relatives had a significantly lower rate of psychotic exacerbation at follow-up. In another study, Okasha et al. (19) aimed to determine the value of families' EE and patients' perception of family criticism in predicting relapse. The relation of family criticism to relapse was found to be statistically significant; however the relationship for perceived criticism and relapse was not significant.

Consequently, it could be stated that PEE is a relatively new concept in research studies such as eating disorder (20). There is substantial research on perceived criticism $(16,21)$ and not on perceived emotional over involvement (PEOI). Although some studies support the effect of PEE on prognosis, other studies fail to note a relationship. The fact that different findings have been found in different cultures and there hasn't any study about that topic in Turkey show the importance of the current research. Furthermore, for clinical interventions, it is valuable to examine the relative roles of $\mathrm{PEE}$ and $\mathrm{EE}$ in order to design intervention programs targeting these perceptions of the patients as well, alongside with family psycho-education programs.

The main aim of the present study is to investigate the effects of both EE and PEE on the positive and negative symptoms of patients with schizophrenia in Turkey. Additionally, one of the aims of the study is to investigate the factor structures of the scales of PEE and EE.

\section{METHOD}

The study is a two-step study having one crosssectional, on a six-month prospective assessment. In the first assessment period, the sample consisted of 116 patients (46 females and 70 males) with a diagnosis of schizophrenia. The sample size was determined by power analysis based on Berksun's study (22). Based 
Table 1: Descriptive data for the patients

\begin{tabular}{lccc} 
& \% (n) & Mean (SD) & Range \\
\hline Age & & $34.76(8.92)$ & $20-60$ \\
Sex & & & \\
$\quad$ Male & & \\
$\quad$ Female & $60.2(62)$ & & \\
Education (years) & $39.8(41)$ & & \\
Marital status & & $8.98(3.77)$ & \\
$\quad$ Single & & & \\
$\quad$ Married & $42.9(44)$ & & \\
$\quad$ Divorced & $41.7(43)$ & & \\
$\quad$ Widowed & $13.6(14)$ & & \\
Currently employed & $1.9(2)$ & & \\
$\quad$ Yes & & & \\
$\quad$ No & $26.2(27)$ & & \\
Duration of illness (years) & $73.8(76)$ & & \\
Number of hospitalizations & & $9.13(8.30)$ & \\
\hline
\end{tabular}

\section{Table 2: Descriptive data for the caregivers}

\begin{tabular}{lccc} 
& $\%(\mathbf{n})$ & Mean (SD) & Range \\
\hline Age & & $46.44(13.69)$ & $19-80$ \\
Education (years) & & $5.22(3.98)$ & $0-18$ \\
Marital status & & & \\
$\quad$ Married & $77.7(80)$ & & \\
$\quad$ Widowed & $12.6(13)$ & & \\
$\quad$ Single & $4.9(5)$ & & \\
$\quad$ Divorced & $4.9(5)$ & & \\
Currently employed & & \\
$\quad$ Yes & $22.3(23)$ & \\
$\quad$ No & $77.7(80)$ & & \\
Relationship to the patient & & & \\
$\quad$ Mother & $38.8(40)$ & & \\
$\quad$ Spouse* & $35.9(37)$ & & \\
$\quad$ Father & $13.6(14)$ & \\
$\quad$ Sibling & $5.8(6)$ & \\
$\quad$ Child & $3.9(4)$ & \\
$\quad$ Other Relatives & $1.9(2)$ & \\
Duration of face-to-face & & $8.51(4.63)$ & \\
contact (hour/day) & &
\end{tabular}

*From among the spouse, $67.5 \%(\mathrm{n}=25)$ were wives and $32.5 \%(\mathrm{n}=12)$ were husbands.

on mean scores $(17.26 \pm 1.67)$ of EES, sample size was calculated as minimum 90 participants with power of $90 \%$ and error of $5 \%$ by using R3.0.1 open source program. Inclusion criteria were the diagnosis of schizophrenia according to DSM-IV (23) and being in a stable position as well as the accessibility and willingness of a key relative willing to participate. The primary caregivers were described as the family members, who had the most face-to-face contact with the patient and who took most of the caregiving burden. Exclusion criteria were being in the acute phase and being mentally retarded. All patients who participated in the first measurement were called to participate for the second measurement of the study. Thirteen of the participants were not included in second measurement for several reasons (such as relapse into an acute episode, inability to participate due to full time employment, migrating to another country, changing the address). Thus, the final sample (taking part in both first and second time assessments) consisted of 103 patients and 103 caregivers. The socio-demographic and illness related characteristics of the 103 patients and their caregivers are given in Tables 1 and 2 .

\section{Measures}

The instruments administered to the caregivers: Caregivers were administered a demographic information sheet containing questions on age, education, marital status and the Expressed Emotion Scale (EES).

Expressed Emotion Scale (EES): The EES (22) was developed in Turkey to measure the level of EE in the family environment. The scale is used in the current study, because previous studies (24-26) have shown that the EES has satisfactory psychometric properties. This 41 -item scale is administered to caregivers of patients with schizophrenia. It is a self-reportinstrument, consisting of two factors, which are Criticism/Hostility $(\mathrm{C} / \mathrm{H})$ and Emotional Over-Involvement (EOI). The format of the response scale is "True" or "False" (true $=1$, false $=0$ ).

The instruments administered to the patients: The research instrument for patients consisted of four parts. The first part (the demographic information sheet) contained questions on the demographic and illness related characteristics.

Positive and Negative Symptom Scale (PANSS): The PANSS was developed by Kay et al. (27). The PANSS is a widely used semi-structured interview designed to evaluate positive and negative symptoms, 
and it also provides a score for general psychopathology. It is a 30-item scale with 16 general psychopathology symptom items, 7 positive-symptom items, and 7 negative-symptom items. The positive symptoms include delusions, hallucinations, suspiciousness/ persecution, and hostility. The items of negative symptoms are blunted affect, emotional withdrawal, and stereotyped thinking. General psychopathology includes somatic concerns, anxiety, depression, motor retardation, attention, and impulse control.

The PANSS was translated and adapted into Turkish and yielded satisfactory psychometric properties (28). In a pilot study conducted before the current study, its inter-rater reliability between the researcher and an experienced psychiatrist was assessed by Cohen's Kappa (29). The results showed that Cohen's Kappa was 0.75 which was significant $(p<0.001)$.

Perceived Expressed Emotion Scale (PEES): For the current study, the items of the EES (22) were transformed to reflect how patients perceive their caregivers' emotional expressions by refining the items into how they perceive their caregivers' EE. The sentences, like "I don't believe that s/he is ill" in EES were transformed into other oriented form, like "S/He doesn't believe that I'm ill". For the reliability and validity study of the PEES, a pilot study was conducted. The sample for the pilot study was comprised of 75 schizophrenic patients (28 females and 47 males). The mean age of the participants was 33 years (range 19-54 years). Patients were asked to answer PEES considering their primary caregiver. For identifying the primary caregiver, patients were asked who were most frequently in face-to-face contact with them, and who took most responsibility for care of the patient. The results of the confirmatory factor analysis for the PEES showed that it had two factors which were similar to the results obtained from the EES $(22,25)$. The first factor, $\mathrm{C} / \mathrm{H}$ consisted of 21 items with factor loadings ranging between 0.35 and 0.77 . The second factor EOI had 19 items with factor loadings ranging between 0.41 and 0.71. Cronbach's Alpha reliability for the whole scale was 0.88 .

Additionally, for evaluating the validity of the PEES, the Family Assessment Device (FAD) (30) which contains 60 items determining how the family functions in different domains were used. The scale consists of seven subscales, Problem Solving, Communication, Roles, Affective Responsiveness, Affective Involvement, and Behavior Control. The correlation analysis showed that $\mathrm{C} / \mathrm{H}$ scale of PEES were positively related to all subscales of FAD, except for Problem Solving which is in line with the expectations and lends support to the validity of the $\mathrm{C} / \mathrm{H}$ scale of PEES. On the other hand, the EOI scale of the PEES were negatively related to Problem Solving $(r=-0.44, p<0.05)$ and positively related to Affective Involvement $(r=0.27, p<0.01)$ and not significantly related to other subscales of $\mathrm{FAD}$.

\section{Procedure}

The participants were recruited among the registered inpatient and outpatient population of Ankara Numune Research and Education Hospital after getting consent and ethical approval from the clinic's directors. Schizoaffective patients or patients with comorbid disorders and mental retardation were excluded from the research. The previous inpatients were reached by taking their phone numbers from their hospital records. Information regarding the general state of the patient, his/her adjustment to the treatment, and the family member taking the most care of the patient were gathered over the phone. Another source for recruiting patients was the outpatient clinic of the hospital. Patients coming to the hospital for their routine control were referred to the first author (G.B.) by the psychiatrists. The aims and the procedures of the study were explained to the patients and they were asked whether they would like to participate in the study. Participation was on a voluntary basis and almost all of those who were contacted agreed to participate. After obtaining the informed consent from the patients and their caregivers and gathering information on characteristics of patients, the PEES, and the PANSS were administered to the patient in a face-to-face format. Following the administration period, patients went out of the room and the caregivers waiting outside were taken into the administration room. The 
socio-demographic form and EES were administered to the caregivers by the researcher. The administration of the questionnaires to the patients and the caregivers took approximately one and a half hour. In order to test the relative effects of PEE and EE of caregivers on the patients' symptom severity, second time assessments were carried out after a six months interval following the first time assessment. The second time assessment was only conducted with the patients who were administered the PANSS. The administration time of the second assessment was about 45 minutes to an hour. Whole study took nine months.

\section{Statistical Analysis}

Data were analyzed using the appropriate programs of SPSS for Windows (31). After conducting Factor Analyses with the measures of PEES and EES, to test the similarity of the factors of PEES and EES, target rotation was carried out. Then, a correlation matrix was created in order to see the correlations between the variables of the study. Following the correlation analyses, repeated measures ANOVA analyses were conducted. Criticism $(\mathrm{C} / \mathrm{H})$ and emotional over-involvement (EOI) scores of the patients and caregivers were used as independent variables, PANSS subscales (for four factors) at the first time and the second time assessments were used as dependent variables.

In order to examine the effects of EE of the caregivers and PEE of the patients (taken at the first time assessment) on the PANSS scores (taken at the first time and the second time assessments), repeated ANOVA was conducted. For this analysis, median split was used to group the scores of $\mathrm{C} / \mathrm{H}$ and $\mathrm{EOI}$ of $\mathrm{EE}$ and $\mathrm{PEE}$ as high and low $\mathrm{C} / \mathrm{H}$; high and low EOI; high and low perceived criticism hostility $(\mathrm{PC} / \mathrm{H})$ and high and low perceived emotional over- involvement (PEOI). Also, in order to examine possible main and interactional effects of the scores of $\mathrm{C} / \mathrm{H}$ and $\mathrm{EOI}$ of caregivers and $\mathrm{PC} / \mathrm{H}$ and PEOI of patients on the positive, negative scores, general psychopathology and total scores of PANSS at the first time and the second time assessments, a $2 \times 2 \times 2$ Mixed Design ANOVA with repeated measures on the last factor (the PANSS scores on the first and second assessments) were conducted. The tukey test was conducted as post hoc analysis to understand the difference between groups.

\section{RESULTS}

Factor analysis of the EES: Principle components with varimax rotation were used for the initial confirmatory factor analysis of the EES items. The results yielded 12 factors which explained $65 \%$ of the variance. After the inspection of the scree plot and previous research results, a two-factor solution appeared to be the most suitable, explaining $27.62 \%$ of the variance. Items with factor loadings above 0.28 were included in the factors; four items not meeting this criterion were excluded from further analysis (item 2, 14, 40 and 41). Table 3 presents the items for the two factors, namely, $\mathrm{C} / \mathrm{H}$ and $\mathrm{EOI}$, their factor loadings, per cent of variance explained by each factor and the Cronbach Alpha values.

Mean factor scores were calculated by reversing the scoring of the negatively loaded items (i.e. items 3,8 , $28,30,36,37,38,39)$ that appeared in the $\mathrm{C} / \mathrm{H}$ factor. The mean factor score for the $\mathrm{C} / \mathrm{H}(\mathrm{M}=0.31, \mathrm{SD}=0.22)$ was lower than the mean score for the $\mathrm{EOI}(\mathrm{M}=0.77$, $\mathrm{SD}=0.20)$. The $\mathrm{C} / \mathrm{H}$ and $\mathrm{EOI}$ of EES were significantly correlated $(r=0.25, p<0.05)$.

Factor analysis of the Perceived Expressed Emotion Scale (PEES): The responses to the items of the PEES were subjected to confirmatory factor analyses using principal components with varimax rotation. Initial analyses yielded 12 factors, explaining $65 \%$ of the variance. After examining the scree plot, the twofactor solution, explaining $28 \%$ of the variance, produced the clearest solution. Items with factor loadings greater than 0.28 were included in the factors; one item not meeting this criterion was excluded from further analysis. Although the factor loadings for items 40 and 41 were higher than 0.28 , these items were excluded from the scale in order to maintain the structural similarity of the EES. Table 4 presents the items for the two factors, $\mathrm{C} / \mathrm{H}$ and $\mathrm{EOI}$, their factor loadings, per cent of variance explained by each factor 
Table 3: Items of the $\mathrm{C} / \mathrm{H}$ and EOI factors of the EES

\section{Item No}

17. S/He interferes with my life.

33. I want to keep away from him/her.

24. Sometimes, I wish that I can get rid of him/her.

10. We can not gand colleaguesong with him/her.

6. His/her existence makes me crazy.

35. Without him/her, everything would be fine.

34. $\mathrm{S} / \mathrm{He}$ gives me a lot of trouble.

30. We get on well.

19. I do not like anything s/he does.

39. I try talking with him/her when s/he is uneasy and unhappy.

38. When s/he gets angry, I try to soothe him/her, I don't stay away from him/her.

8. I like and I admire some aspects of him/her.

25. I keep away from him/her when s/he is uneasy and unhappy.

13. $\mathrm{S} / \mathrm{He}$ hurts and offends me.

11. I no longer care for him/her and stay away from him/her.

28. We are alike as character and habit.

1. I think that $\mathrm{s} /$ he does certain things on purpose and this makes me angry.

3. I enjoy talking with him/her.

20. I do not like the way S/he dresses up and I tell this to him/her.

36. When I face a difficulty I can cope with it

22. I worry even for a slightest thing that may happen to him/her

31. My mind is always full of him/her, I can not think of anything else.

9. I frequently give him/her advice.

15. I cherish him/her.

23. I attend to everything about him/her.

5. I try to learn everything, even private matters about him/her.

26. I often warm him/her to do what s/he does in an orderly and systematic manner.

32. I frequently criticize him/her and want him/her to correct himself/herself.

16. When we are together I only show attention to him/her and nothing else.

21. I want him/her to behave in ways I expect him/her to behave.

18. Due to his/her illness I feel that the whole world collapsed on me.

4. For me, his/her wishes are more important than the rest of the families'.

27. His/her hospitalization makes me desperate and I cannot part from him/her.

29. I want him/her to correct his/her mistakes.

7. I keep on thinking about what we did wrong.

12. I am the one in our family who takes care of everything about him/her.
37. It gives me pleasure to attend to everything about him/her.

Factor 1

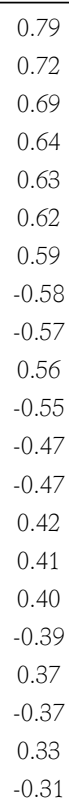

0.72

0.69

0.64

0.63

0.62

0.59

$-0.58$

$-0.57$

0.56

0.55

$-0.47$

$-0.47$

0.42

0.41

0.40

0.39

0.37

$-0.37$

0.33

$-0.31$

\section{Item excluded}

2. I don't believe that s/he is ill

14. I listen to all his/her ideas.

40. I think that s/he exaggerates his/her illness.

41. I give him/her emotional support when s/he feels down.

Factor 1: C/H (variance explained 17\%; Cronbach's alpha=0.87), Factor 2: EOI (variance explained 10\%; Cronbach's alpha=0.78)

and the Cronbach Alpha values.

The mean factor score for the $\mathrm{C} / \mathrm{H}(\mathrm{M}=0.40$, $\mathrm{SD}=0.22$ ) was lower than the mean score for the $\mathrm{EOI}$ factor $(\mathrm{M}=0.67, \mathrm{SD}=0.23)$. The $\mathrm{C} / \mathrm{H}$ and $\mathrm{EOI}$ of PEES were not significantly correlated $(\mathrm{r}=-0.107, \mathrm{p}>0.05)$.

In order to test the similarity of the factor structures obtained from the scales, target rotations of the PEES and the EES factor matrices were carried out. Proportionality (Tucker's phi) coefficients were calculated to assess the similarity of the PEES and the EES factor matrices. Proportionality coefficient values above 0.90 indicate sufficient similarity between the factors (32). The values for Tucker's phi were 0.92 for the PEES and 0.92 for the EES. Hence, the factor 


\section{Table 4: Items of the $\mathrm{C} / \mathrm{H}$ and EOI factors of the PEES}

\section{Item No}

24. Sometimes, s/he wishes that $\mathrm{s} /$ he can get rid of me.

34. S/He thinks that I give her/him a lot of trouble.

33. S/He wants to keep away from me.

32. $\mathrm{S} / \mathrm{He}$ frequently criticizes me and wants me to correct myself.

10. $\mathrm{S} / \mathrm{He}$ can not chant colleague song with me.

35. $\mathrm{S} / \mathrm{He}$ thinks that without me, everything would be fine.

13. $\mathrm{S} / \mathrm{He}$ hurts and offends me.

6. My existence makes him/her crazy.

19. S/He doesn't like anything I do.

18. Due to my illness s/he feels that the whole world collapsed on her/him.

1. S/He thinks that I do certain things on purpose and this makes her/him angry.

7. S/He keeps on thinking about what s/he did wrong.

21. $\mathrm{S} / \mathrm{He}$ wants me to behave in ways s/he expects me to behave.

11. S/He no longer cares for me and stays away from me.

20. S/He doesn't like the way I dress up and s/he tells this to me.

29. $\mathrm{S} / \mathrm{He}$ wants me to correct my mistakes.

17. S/He thinks that I interfere with her/him life.

26. S/He often warns me to do what I do in an orderly and systematic manner.

5. $\mathrm{S} / \mathrm{He}$ tries to learn everything, even private matters about me.

25. S/He keeps away from me when I am uneasy and unhappy.

15. $\mathrm{S} / \mathrm{He}$ cherishes me.

14. S/He listens to all my ideas.

37. It gives her/him pleasure to attend to everything about me.

30. S/He thinks that we get on well.

38. When I get angry s/he tries to soothe me, s/he doesn't stay away from me.

39. S/He tries talking with me when I'm uneasy and unhappy.

16. When we are together s/he only shows attention to me and nothing else.

22. $\mathrm{S} / \mathrm{He}$ worries even for a slightest thing that may happen to me.

3. S/He enjoys talking with me.

12. $\mathrm{S} / \mathrm{He}$ is the one in our family who takes care of everything about me.

23. S/He attends to everything about me.

27. My hospitalization makes her/him desperate and s/he cannot part from me.

28. $\mathrm{S} / \mathrm{He}$ thinks that we are alike as character and habit.

31. Her/his mind is always full of me, s/he can not think of anything else.

8. $\mathrm{S} / \mathrm{He}$ likes and admires some aspects of me.

4. For her/him, my wishes are more important than the rest of the families'.

9. $\mathrm{S} / \mathrm{He}$ frequently gives me advice.
Factor 2

\begin{tabular}{c} 
Factor \\
\hline 0.67 \\
0.62 \\
0.56 \\
0.55 \\
0.54 \\
0.53 \\
0.53 \\
0.52 \\
0.51 \\
0.49 \\
0.49 \\
0.48 \\
0.47 \\
0.46 \\
0.45 \\
0.43 \\
0.40 \\
0.39 \\
0.37 \\
0.28
\end{tabular}

0.66

0.65

0.64

0.60

0.59

0.53

0.52

0.48

0.48

0.45

0.44

0.43

0.41

0.37

0.37

0.34

0.30

\section{Item Excluded}

2. S/He doesn't believe that I'm ill.

41. $\mathrm{S} / \mathrm{He}$ gives me emotional support when I feel down.

Factor 1: $\mathrm{C} / \mathrm{H}$ (variance explained 16.01) (Cronbach alpha=0.83), Factor 2: $\mathrm{EOI}$ (variance explained 11.66\%; Cronbach alpha $=0.81$ )

structures of the PEES and the EES were found to be virtually identical.

\section{Effects of EE and PEE on Psychopathology:}

The means, standard deviations and ranges of all variables are presented in the Table 5. An independentsamples t-test was conducted to compare PANSS scores in the first and second assessments. There was a significant difference in the scores for PANSS positive at first assessment $(M=15.14, S D=5.22)$ and second assessment ( $M=14.07, \mathrm{SD}=5.46) ; \mathrm{t}(102)=2.40, \mathrm{p}=0.02$. There was a significant difference in the scores for PANSS general psychopathology at first assessment $(M=27.86, S D=6.42)$ and second assessment $(M=25.30, S D=5.55) ; t(102)=4.23, p<0.001$. There was a significant difference in the scores for PANSS 
total at first assessment $(\mathrm{M}=57.37, \mathrm{SD}=13.28)$ and second assessment $(M=52.97, S D=11.91) ; t(102)=3.63$, $\mathrm{p}<0.001$

A Pearson product-moment correlation coefficient was computed to assess the relationship between the EES and PEES. C/H of EES was positively and significantly related to EOI of EES $(r=0.25, p<0.05)$ and $\mathrm{C} / \mathrm{H}$ of PEES $(r=0.34, p<0.01)$. EOI of EES was positively and significantly related to $\mathrm{C} / \mathrm{H}$ of $\mathrm{PEES}$ $(r=0.27, p<0.01)$.

First of all effects of EE and PEE on psychopathology, for the scores of PANSS positive, the main effect of $\mathrm{PC} / \mathrm{H}$ of patients was significant $(\mathrm{F}[1,99]=7.77, \mathrm{p}<0.01)$. The high $\mathrm{PC} / \mathrm{H}$ group $(\mathrm{M}=16.13)$ had significantly higher scores on PANSS positive symptoms than the low $\mathrm{PC} / \mathrm{H}$ group $(\mathrm{M}=13.55)$. The main effect of $\mathrm{C} / \mathrm{H}$ of the caregivers was not significant $(F[1,99]=3.29, p>0.05)$.

\begin{tabular}{|c|c|c|c|}
\hline & Mean & SD & Range \\
\hline \multicolumn{4}{|l|}{ PEES } \\
\hline $\mathrm{C} / \mathrm{H}$ & 0.39 & 0.21 & $0.00-0.90$ \\
\hline EOI & 0.66 & 0.22 & $0.00-1.00$ \\
\hline \multicolumn{4}{|l|}{ EES } \\
\hline $\mathrm{C} / \mathrm{H}$ & 0.26 & 0.22 & $0.00-0.83$ \\
\hline EOI & 0.75 & 0.20 & $0.15-1.00$ \\
\hline \multicolumn{4}{|l|}{ PANSS (time 1) } \\
\hline Positive & 15.04 & 5.20 & $7-28$ \\
\hline Negative & 14.47 & 5.24 & $7-37$ \\
\hline General Psychopathology & 28.01 & 6.29 & $16-52$ \\
\hline Total & 57.52 & 13.08 & $32-109$ \\
\hline \multicolumn{4}{|l|}{ PANSS (time 2) } \\
\hline Positive & 14.07 & 5.46 & $7-30$ \\
\hline Negative & 13.80 & 4.55 & $7-30$ \\
\hline General Psychopathology & 25.30 & 5.55 & $16-41$ \\
\hline Total & 52.97 & 11.91 & $32-81$ \\
\hline
\end{tabular}

PEES: Perceived Expressed Emotion Scale, C/H: Criticism/Hostility Subscale, EOI: Emotional Over-Involvement Subscale, EES: Expressed Emotion Scale,

PANSS: Positive and Negative Symptom Scale
In addition, the main effect of the PEOI of the patients was significant $(F[1,99]=6.97, p<0.01)$. The low PEOI patients $(M=15.64)$ had significantly higher scores than the high PEOI patients $(M=13.20)$ on PANSS positive scores. The main effect of the EOI of the caregivers was not significant $(\mathrm{F}[1,99]=2.81, \mathrm{p}>0.05)$.

Secondly, the results for the PANSS negative scores were similar to the results of the PANSS positive. The main effect of $\mathrm{PC} / \mathrm{H}$ of patients was significant $(\mathrm{F}[1,99]=7.30, \mathrm{p}<0.01)$. The high $\mathrm{PC} / \mathrm{H}$ group patients $(M=15.33)$ were significantly higher than the patients in the low $\mathrm{PC} / \mathrm{H}$ group $(\mathrm{M}=13.16)$ on PANSS negative scores. The main effect of $\mathrm{C} / \mathrm{H}$ of caregivers was not significant $(F[1,99]=1.85, p>0.05)$. The main effects of the EOI of caregivers ( $F[1,99]=0.19$, $\mathrm{p}>$.05) and the PEOI of the patients were not significant $(\mathrm{F}[1,99]=3.14, \mathrm{p}>0.05)$.

For the PANSS general psychopathology scores, the main effects of $\mathrm{C} / \mathrm{H}$ of caregivers $(\mathrm{F}[1,99]=2.93, \mathrm{p}>0.05)$ and $\mathrm{PC} / \mathrm{H}$ of patients $(\mathrm{F}[1,99]=2.86, \mathrm{p}>0.05)$ were not significant. On the other hand, the main effect of PEOI of patients was significant $(F[1,99]=6.04, p<0.05)$. The low PEOI group $(M=27.61)$ had significantly higher scores than the high PEOI group $(M=25.16)$ on the PANSS general psychopathology scores.

Lastly, for the PANSS total score, the main effect of $\mathrm{PC} / \mathrm{H}$ of patients was found $(\mathrm{F}[1,99]=8.78, \mathrm{p}<0.01)$. The high $\mathrm{PC} / \mathrm{H}$ group $(\mathrm{M}=58.80)$ had significantly higher effect on the PANSS total score than the low $\mathrm{PC} / \mathrm{H}$ group $(M=52.60)$. Also, the main effect of $\mathrm{C} / \mathrm{H}$ of caregivers was significant $(F[1,99]=4.11, p<0.05)$. In other words, the patients whose caregivers had high $\mathrm{C} / \mathrm{H}$ scores obtained significantly higher scores on the PANSS total score $(M=57.82)$ than the patients whose caregivers got low scores of $\mathrm{C} / \mathrm{H}(\mathrm{M}=53.58)$. The main

Table 6: Summary of All Anova Analyses

\begin{tabular}{lccccccccccccc} 
& \multicolumn{3}{c}{ CAREGIVER C/H } & \multicolumn{3}{c}{ CAREGIVER EOI } & \multicolumn{3}{c}{ PERCEIVED C/H } & \multicolumn{2}{c}{ PERCEIVED EOI } \\
\cline { 2 - 12 } & $\mathbf{F}(\mathbf{1 , 9 9 )}$ & $\mathbf{M}_{\text {LOW }}$ & $\mathbf{M}_{\text {HIGH }}$ & $\mathbf{F}(\mathbf{1 , 9 9 )}$ & $\mathbf{M}_{\text {LOW }}$ & $\mathbf{M}_{\text {HIGH }}$ & $\mathbf{F}(\mathbf{1 , 9 9})$ & $\mathbf{M}_{\text {LOW }}$ & $\mathbf{M}_{\text {HIGH }}$ & $\mathbf{F}(\mathbf{1 , 9 9})$ & $\mathbf{M}_{\text {LOW }}$ & $\mathbf{M}_{\text {HIGH }}$ \\
\hline PANSS positive & - & - & - & - & - & - & $7.77^{* *}$ & 13.55 & 16.13 & $6.97^{* *}$ & 15.64 & 13.20 \\
PANSS negative & - & - & - & - & - & - & $7.30^{* *}$ & 13.16 & 15.33 & - & - & - \\
PANSS general psychopathology & - & - & - & - & - & - & $6.04^{* *}$ & 27.61 & 25.16 & - & - & - \\
PANSS total & $4.11^{*}$ & 53.58 & 57.82 & - & - & - & $8.78^{* *}$ & 52.60 & 58.80 & $8.76^{* *}$ & 57.77 & 51.59 \\
\hline
\end{tabular}

${ }^{*} \mathrm{p}<0.05,{ }^{* *} \mathrm{p}<0.01,-$ n.s. 
effect of PEOI of patients was found $(F[1,99]=8.76$, $\mathrm{p}<0.01$ ). The low PEOI group ( $M=57.77$ ) had significantly higher scores on the PANSS total score than the high PEOI group ( $M=51.59)$. The main effect of EOI of caregivers was not significant $(F[1,99]=1.88, p>0.05)$.

Even though we found main effects mostly for the $\mathrm{PC} / \mathrm{H}$ and PEOI for the same factors, there was no interactional effect between the scores of $\mathrm{C} / \mathrm{H}$ and $\mathrm{EOI}$ of caregivers and $\mathrm{PC} / \mathrm{H}$ and $\mathrm{PEOI}$ of patients on the PANSS positive, negative, general psychopathology, and total scores at the first time and the second time assessments. Table 6 presents the summary of all ANOVA analysis.

\section{DISCUSSION}

The main aim of the study was to evaluate the impact of expressed emotion of caregivers and the perception of EE by patients on positive and negative symptoms. The results suggested that PEE is a more distinctive factor affecting symptom severity than EE. In the literature, generally the predictive power of family's EE on relapse is examined $(33,34)$. Therefore, the current study has a meaningful contribution to show the crosscultural value of PEE and especially EOI on schizophrenic patients. The relationship between high EOI and poor outcome is inconsistent across cultures. High EOI predicts both relapse and re-hospitalisation (35). However, EOI may not necessarily be detrimental in all cultures (36).

According to the findings regarding the comparisons between EES and PEES, caregivers reported themselves as lower on $\mathrm{C} / \mathrm{H}$ and higher on EOI contrary to how the patients perceive. These results were found to be consistent with the study of Ozden (26) who presumed that Turkish families were low on $\mathrm{C} / \mathrm{H}$. According to Ozden, the families' defensive attitude toward the idea of being evaluated could be an explanation for their results. Caregivers might have reported that they had low $\mathrm{C} / \mathrm{H}$ and high $\mathrm{EOI}$, due to social desirability. Karanci and Inandilar (25) also found that caregivers' EOI was higher than their $\mathrm{C} / \mathrm{H}$ in the Turkish culture, and this present study was a replication of this finding. In the current study, the $\mathrm{C} / \mathrm{H}$ of caregivers' $\mathrm{EE}$ was found to have only a significant effect on the total scores of PANSS. The role of EOI on relapse is not widely stressed in the literature. A handful of studies from certain cultural backgrounds (e.g. Mexican-American populations) have found that high positive affect (warmth) correlates with lower levels of relapse in schizophrenia. The EOI of caregivers' EE was shown to be a more sensitive predictor of relapse by Gutierrez in 1988 (cited in 37). In other studies, it has been taken as a less distinctive predictor. For example, in the study of Vaughn et al. (35) when they compared Anglo-American and British families, Anglo-American families were found to have high EE and the British families were found to be less $\mathrm{C} / \mathrm{H}$. Both cultures were found to have low and equal EOI. Similarly, in a study conducted in Iran, preceding EOI, hostility was found to be the strongest contributor of high $\mathrm{EE}$ (38).

Cross-cultural studies showed that EE was high in Western cultures, whereas it was low in rural and Eastern countries (39). Although Turkey has several features similar to Western countries, it is considered an Eastern country. Thus, while interpreting the results of our study, it would be appropriate to make comparisons with Eastern countries. Examining EE in the families of schizophrenic patients in both urban and rural populations in India, Wig et al. (39) found that high EE was very rare with low critical comments and being less over-involved. These findings were consistent with the results of the current study. According to El Islam (40), in Eastern cultures, especially within extended families, supporting individuals with mental illness and decreasing their expectations is a common situation. Similarly, Egyptian families believed that the care of a sick family member was their obligation and considered to be right behavior for essential caregivers. High EE could be viewed as a kind of social trait in many families. Criticism might also be taken as a sign of care and interest in any Egyptian enmeshed family (19). Consistent with the previous studies mentioned above, in Turkey, families continue to support patients who are a burden to the family due to their illness and who have been unemployed for a long time (26). In addition to the findings regarding Eastern cultures, López et al. (41) indicated that family 
warmth was a significant protective factor against relapse for Mexican Americans. However, for Anglo Americans, family criticism was a significant risk factor. In addition, Rosenfarb et al. (42) stated that discordance between caregivers' EE and patients' PEE was the result of cultural differences in the interpretation of criticism. It was suggested that African American patients evaluated critical attitudes to be a reflection of caring and involvement. In sum, these studies suggested the fact that sociocultural context shaped the pathways by which family processes were related to the course of illness. Martins et al. (6) hypothesized that in Brazilian society, patient caregivers mostly had low EE. Cases of high EE were explained by having high EOI. Martins' participants were mostly mothers and they markedly had overprotective and self-sacrificing attitudes. In our study, the relationship between types of caregivers' and factors of expressed emotion was not investigated. However, similar to the study conducted by Martins et al. the majority of the caregivers were mothers of the patients in our study. Hence, this relation would be inquired in the further study.

In consideration of the scores of $\mathrm{C} / \mathrm{H}$ and $\mathrm{EOI}$ of caregivers on the PANNS scores were notfound significant mostly, PEE is to be likely an important construct. Since $\mathrm{EE}$ is a reciprocal interaction, patients' perceptions of their families' attitudes are important as well as families' attitudes. Until recently, the importance of patients' perceptions of their families' attitudes were not given the necessary importance. However, although not many, there are some studies in the literature considering the importance of PEE $(18,43)$. Thompson et al. (15) found that overall patients' perceptions and caregivers' attitudes nearly overlapped. They found that patients with high EE caregivers perceived them as highly critical. Patients' perceptions of critical behavior rather than the EE ratings were associated with a high risk of relapse. Besides the effect of perceived $\mathrm{C} / \mathrm{H}$ on the relapse, there are other studies that show the significance of PEOI on relapse. For example, Warner and Atkinson (44) found that patients who perceived their families as less caring or more over-involved had a more severe course of illness than patients who perceived their families as more caring and less over-involved.
Furthermore, Scott et al. (17) found that the best predictor of relapse was the patients' expectations of how their families perceived them. In another study conducted by Lebell et al. (18) this idea was supported. They found that the patients' perceptions of their caregivers' attitudes towards themselves were highly correlated with the caregivers' self-reported attitudes. Remarkably, only the patients' perceptions predicted outcome. Patients with positive perceptions of their caregivers' attitudes had a significantly lower rate of relapse at one year follow-up. According to our results, PEE was shown to be a more robust construct than the EE reported by the caregiver.

The important point was the fact that $\mathrm{C} / \mathrm{H}$ of $\mathrm{PEE}$ was found to be a toxic element. Patients who perceived high $\mathrm{C} / \mathrm{H}$ scored higher on positive/negative symptoms and total PANSS than patients who perceived low $\mathrm{C} / \mathrm{H}$. If patients perceive high $\mathrm{C} / \mathrm{H}$ in the family climate, they are likely to experience more severe positive symptoms such as delusions, hallucinatory behavior, grandiosity, suspiciousness/ persecution, and hostility. Additionally increase in negative symptoms such as blunted affect, emotional withdrawal and total scores were seen together with high perceived $\mathrm{C} / \mathrm{H}$. There are also similar studies finding perceived $\mathrm{C} / \mathrm{H}$ toxic. For instance, Thompson et al. (15) found that EOI of PEE did not predict outcome, however criticism of PEE predicted high risk of psychotic exacerbation within a year. In the same study, it was demonstrated that a large number of patients who perceived high $\mathrm{C} / \mathrm{H}$ in their families relapsed. Similarly, Hooley and Teasdale (11) showed that perceived $\mathrm{C} / \mathrm{H}$ predicted relapse in one-year follow up. Bachmann et al. (13) found that perceived $\mathrm{C} / \mathrm{H}$ was a beneficial tool for predicting relapse and that high $\mathrm{C} / \mathrm{H}$ was more associated with relapse than EOI for schizophrenia. On the other hand, Okasha et al. (19) could not find a significant relationship between perceived $\mathrm{C} / \mathrm{H}$ and relapse.

Whereas $\mathrm{C} / \mathrm{H}$ of PEES was a detrimental component, high PEOI was found to be a beneficial element. On the other hand, patients who perceived low EOI had high scores on positive symptoms, general psychopathology, and total scores of PANSS. Hence, it could be concluded 
that low perceived EOI has a detrimental effect on symptom severity.

According to our results, EOI of caregivers did not have a significant effect on symptom severity that was measured by PANSS. Similarly, Bentsen et al. (43) could not find a significant relationship between EOI and symptoms assessed by a researcher. On the other side, Breitborde et al. (45) indicated that the relationship between the EOI and relapse was curvilinear and that high levels of EOI exerted a toxic effect on the course of illness whereas medium levels of EOI were protective. Similarly, in a recent study with patients in a first episode of psychosis from United Kingdom, Lee et al. (46) found the patients were less likely to relapse within 6 and 12 -month follow-up periods, when they perceived more positive affect from the family. The researchers concluded that patients' perceptions of positive affect appeared to be stronger predictors of relapse outcome than criticism and other EE variables.

Overall, as a result of these discussions it could be stated that perceived $\mathrm{C} / \mathrm{H}$ of patients was a more distinctive factor than $\mathrm{C} / \mathrm{H}$ of caregivers on positive and negative symptoms of PANSS. Only on total scores of PANSS, both perceived $\mathrm{C} / \mathrm{H}$ of patients and $\mathrm{C} / \mathrm{H}$ of caregivers had been found to have a main effect. Perceived EOI of patients was a more indicative factor than EOI of caregivers in all subscales of PANSS, except for negative symptoms.

However, there are some limitations. Due to time limitations, relapses were examined for six months in the study. Nevertheless, in a meta-analysis, the researchers found that follow-up periods ranged from 6 months to 7 years (36). Follow up period of 6 -month is reasonable in the present case. As another limitation, patients at the first assessment were chosen from outpatients rather than in-patients. Another limitation of the study is the fact that only one caregiver was interviewed per family and denoted as the main caregiver. There are studies that criticize including only one family member within research $(35,45,47)$. However, in several studies in the literature $(13,14)$ only one family member was assessed as caregiver. In order to identify the appropriate choices of treatment for the chronically ill schizophrenic patients, it is important to evaluate the effects of family's EE and PEE on symptom severity. To sum, the current study can provide guidelines to support services for schizophrenic patients.

Acknowledgement: We would like to thank Prof. Erol Goka, M.D., Director of 1st Psychiatry Clinic of Ankara Numune Research and Education Hospital, for motivating to carry out this study.

\section{REFERENCES}

1. Barrowclough C, Hooley JM. Attributions and expressed emotion: a review. Clin Psychol Rev 2003; 23:849-880. [CrossRef]

2. Kazarian SS. The measurement of expressed emotion: a review. Can J Psychiatry 1992; 37:51-56.

3. Hooley JM. Expressed emotion and relapse of psychopathology. Annu Rev Clin Psychol 2007; 3:329-352. [CrossRef]

4. Jenkins JH, Karno M. The meaning of expressed emotion: theoretical issues raised by cross-cultural research. Am J Psychiatry 1992; 149:9-21. [CrossRef]

5. Kuipers L. Expressed emotion in 1991. Soc Psychiatry Psychiatr Epidemiol 1992; 27:1-3. [CrossRef]

6. Martins C, de Lemos AI, Bebbington PE. A Portuguese/Brazilian study of expressed emotion. Soc Psychiatry Psychiatr Epidemiol 1992; 27:22-27. [CrossRef]

7. Shimodera S, Inoue S, Mino Y, Tanaka S, Kii M, Motoki Y. Expressed emotion and psychoeducational intervention for relatives of patients with schizophrenia: a randomized controlled study in Japan. Psychiatry Res 2000; 96:141-148. [CrossRef]

8. Stengård E. Educational intervention for the relatives of schizophrenia patients in Finland. Nord J Psychiatry 2003; 57:271-277. [CrossRef]

9. Tomaras V, Mavreas V, Economou M, Ioannovich E, Karydi $\mathrm{V}$, Stefanis C. The effect of family intervention on chronic schizophrenics under individual psychosocial treatment: a 3-year study. Soc Psychiatry Psychiatr Epidemiol 2000; 35:487-493. [CrossRef]

10. Wuerker AK, Long JD, Haas GL, Bellack AS. Interpersonal control, expressed emotion, and change in symptoms in families of persons with schizophrenia. Schizophr Res 2002; 58:281-292.

\section{[CrossRef]}


11. Hooley JM, Teasdale JD. Predictors of relapse in unipolar depressives: expressed emotion, marital distress, and perceived criticism. J Abnorm Psychol 1989; 98:229-235. [CrossRef]

12. Weisman AG, Rosales GA, Kymalainen JA, Armesto JC. Ethnicity, expressed emotion, and schizophrenia patients' perceptions of their family members' criticism. J Nerv Ment Dis 2006; 194:644649. [CrossRef]

13. Bachmann S, Bottmer C, Jacob S, Schröder J. Perceived criticism in schizophrenia: a comparison of instruments for the assessment of the patient's perspective and its relation to relatives' expressed emotion. Psychiatry Res 2006; 142:167-175. [CrossRef]

14. Scazufca M, Kuipers E, Menezes PR. Perception of negative emotions in close relatives by patients with schizophrenia. Br J Clin Psychol 2001; 40:167-175. [CrossRef]

15. Tompson MC, Goldstein MJ, Lebell MB, Mintz LI, Marder SR, Mintz J. Schizophrenic patients' perceptions of their relatives' attitudes. Psychiatry Res 1995; 57:155-167. [CrossRef]

16. Renshaw $\mathrm{KD}$. The predictive, convergent, and discriminant validity of perceived criticism: a review. Clin Psychol Rev 2008; 28:521-534. [CrossRef]

17. Scott RD, Fagin L, Winter D. The importance of the role of the patient in the outcome of schizophrenia. Br J Psychiatry 1993; 163:62-68. [CrossRef]

18. Lebell MB, Marder SR, Mintz J, Mintz LI, Tompson M, Wirshing W, Johnston-Cronk K, McKenzie J. Patients' perceptions of family emotional climate and outcome in schizophrenia. Br J Psychiatry 1993; 162:751-754. [CrossRef]

19. Okasha A, El Akabawi AS, Snyder KS, Wilson AK, Youssef I, El Dawla AS. Expressed emotion, perceived criticism and relapse in depression: a replication in an Egyptian community. Am J Psychiatry 1994; 151:1001-1005. [CrossRef]

20. Medina-Pradas C, Navarro JB, López SR, Grau A, Obiols JE. Further development of a scale of perceived expressed emotion and its evaluation in a sample of patients with eating disorders. Psychiatry Res 2011; 190:291-296. [CrossRef]

21. Kronmüller KT, Backenstrass M, Victor D, Postelnicu I, Schenkenbach C, Joest K, Fiedler P, Mundt C. Expressed emotion, perceived criticism and 10-year outcome of depression. Psychiatry Res 2008; 159:50-55. [CrossRef]

22. Berksun OE. Family factor in schizophrenia: Development and adaptation of expressed emotion scale. Postgraduate Thesis, University of Ankara, Ankara, 1992. (Turkish)

23. American Psychiatric Association. DSM-IV: Diagnostic and Statistical Manual of Mental Disorders. Fourth Ed. Washington DC: American Psychiatric Publishing, 2000.
24. Cansever A. The effect of expressed emotion of the family on the prognosis of schizophrenic disorder. Postgraduate Thesis, Gulhane Military Medicine Academia, 1994. (Turkish)

25. Karanci AN, Inandilar $\mathrm{H}$. Predictors of components of expressed emotion in major caregivers of Turkish patients with schizophrenia. Soc Psychiatry Psychiatr Epidemiol 2002; 37:80 88. [CrossRef]

26. Ozden A. The relationship between relapse of schizophrenic patients and expressed emotion on their families. Postgraduate Thesis, University of Ankara, Ankara, 1995. (Turkish)

27. Kay SR, Fiszbein A, Opler LA. The positive and negative syndrome scale (PANSS) for schizophrenia. Schizophr Bull 1987; 13:261-276. [CrossRef]

28. Yagcioglu AEA, Batur S, Tiryaki A, Gogus A. The Reliability and Validity of Turkish version of Positive and Negative Symptom Scale (PANSS). Turk Psikoloji Derg 1999; 14:23-34. (Turkish)

29. Cohen JA. A coefficient of agreement for nominal scales. Educational and Psychological Measurement 1960; 20:37-46. [CrossRef]

30. Epstein NB, Baldwin LM, Bishop DS. The McMaster family assessment device. Journal of Marital and Family Therapy 1983 9:171-180. [CrossRef]

31. Green SB, Salkind NJ, Akey TM. Using SPSS for Windows: Analyzing and Understanding Data. First Ed. New Jersey: Prentice Hall, 1997.

32. van de Vijver F, Leung K. Methods and Data Analysis for Crosscultural Research. London: Sage Publications, 1997.

33. Barrelet L, Ferrero F, Szigethy L, Giddey C, Pellizer G. Expressed emotion and first-admission schizophrenia, Nine-month followup in a French cultural environment. Br J Psychiatry 1990; 156:357-362. [CrossRef]

34. Butzlaff RL, Hooley JM. Expressed emotion and psychiatric relapse: a meta-analysis. Arch Gen Psychiatry 1998; 55:547-552. [CrossRef]

35. Vaughn CE, Snyder KS, Jones S, Freeman WB, Fallon IR. Family factors in schizophrenic relapse. Replication in California of British research on expressed emotion. Arch Gen Psychiatry 1984; 41:1169-1177. [CrossRef]

36. Singh SP, Harley K, Suhail K. Cultural specificity of emotional overinvolvement: a systematic review. Schizophrenia Bull 2011; 39:449-463. [CrossRef]

37. Kavanagh DJ. Recent developments in expressed emotion and schizophrenia. Br J Psychiatry 1992; 160:601-620. [CrossRef] 
38. Mottaghipour Y, Pourmand D, Maleki H, Davidian L. Expressed emotion and the course of schizophrenia in Iran. Soc Psychiatry Psychiatr Epidemiol 2001; 36:195-199. [CrossRef]

39. Wig NN, Menon DK, Bedi H, Ghosh A, Kuipers L, Leff J, Korten A, Day R, Sartorius N, Ernberg G, Jablensky A. Expressed emotion and schizophrenia in North India. I. Cross-cultural transfer of ratings of relatives' expressed emotion. Br J Psychiatry 1987; 151:156-160. [CrossRef]

40. El-Islam EF. A better outlook for schizophrenics living in extended families. Br J Psychiatry 1979; 135:343-347. [CrossRef]

41. López SR, Nelson Hipke K, Polo AJ, Jenkins JH, Karno M, Vaughn C, Snyder KS. Ethnicity, expressed emotion, attributions, and course of schizophrenia: family warmth matters. J Abnorm Psychol 2004; 113:428-439. [CrossRef]

42. Rosenfarb IS, Bellack AS, Aziz N, Kratz KM, Sayers S. Race, family interactions, and patient stabilization in schizophrenia. J Abnorm Psychol 2004; 113:109-115. [CrossRef]
43. Bentsen H, Boye B, Munkvold OG, Notland TH, Lersbryggen $\mathrm{AB}$, Oskarsson $\mathrm{KH}$, Ulstein I, Uren G, Bjǿrge $\mathrm{H}$, Berg-Larsen $\mathrm{R}$, Lingjærde $O$, Malt UF. Emotional overinvolvement in parents of patients with schizophrenia or related psychosis: Demographic and clinical predictors. Br J Psychiatry 1996; 169:622-630. [CrossRef]

44. Warner R, Atkinson M. The relationship between schizophrenic patients' perceptions of their parents and the course of their illness. Br J Psychiatry 1988; 153:344-353. [CrossRef]

45. Breitborde NJK, López SR, Wickens TD, Jenkins JH, Karno $M$. Toward specifying the nature of the relationship between expressed emotion and schizophrenic relapse: the utility of curvilinear models. Int J Methods Psychiatr Res 2007; 16:1-10.

\section{[CrossRef]}

46. Lee G, Barrowclough C, Lobban F. Positive affect in the family environment protects against relapse in first-episode psychosis. Soc Psychiatry Psychiatr Epidemiol 2014; 49:367-376. [CrossRef]

47. Falloon IRH. Expressed emotion: current status. Psychol Med 1988; 18:269-274. [CrossRef] 